\title{
ACTIVITY OF LIQUID SMOKE OF TOBACCO STEM WASTE AS AN INSECTICIDE ON Spodoptera litura Fabricius LARVAE
}

\author{
AKTIVITAS ASAP CAIR LIMBAH BATANG TEMBAKAU SEBAGAI INSEKTISIDA \\ TERHADAP LARVA Spodoptera litura Fabricius
}

\author{
Heri Prabowo $^{1) *}$, Edhi Martono ${ }^{2)}$, \& Witjaksono ${ }^{2)}$ \\ ${ }^{1)}$ Indonesian Sweetener and Fiber Crops Research Institute \\ Jln. Raya Karangploso, Po Box 199, Malang 65152 \\ ${ }^{2)}$ Department of Plant Pest and Disease, Faculty of Agriculture, Universitas Gadjah Mada \\ Jln. Flora 1, Bulaksumur, Sleman, Yogyakarta 55281 \\ *Corresponding author.E-mail: heri_prabowo@mail.litbang.pertanian.go.id
}

\begin{abstract}
The use of chemical insecticide in crop protection around the world has resulted in disturbances of the environment. Therefore, it is necessary to develop for environmentally friendly insect pest management techniques such as the activity of liquid smoke made from tobacco stem waste as an insecticide to Spodoptera litura. Activity of liquid smoke of tobacco stem waste was carried out at the laboratory condition. The results showed that the application of liquid smoke by using the spraying method (direct method) showed better results compared to the results of feeding method (indirect method). Lethal concentration (LC) at 5 days after treatment, $\mathrm{LC}_{50}$ and $\mathrm{LC}_{75}$ values the direct method of $2.9 \%$ and $8.87 \%$, while the indirect method of $6,99 \%$ and $21.03 \%$. The sub lethal concentration did not cause mortality of $S$. litura larvae, but inhibited the growth such as indicated by lower weight of larval and pupal in treated larvae than in control. Liquid smoke of tobacco stem waste has activity as an insecticide to S. litura.
\end{abstract}

Keywords: activity, liquid smoke, Spodoptera litura, tobacco stem waste

\section{INTISARI}

Penggunaan pestisida kimia dalam pengendalian hama di dunia telah menimbulkan gangguan terhadap lingkungan. Maka teknik pengendalian hama yang ramah lingkungan perlu dikembangkan, misalnya aktivitas asap cair limbah batang tembakau sebagai insektisida pada Spodoptera litura. Aktivitas asap cair limbah batang tembakau dilakukan pada kondisi laboratorium. Hasil penelitian menunjukkan bahwa aplikasi asap cair secara langsung (metode semprot) lebih efektif daripada tidak langsung (metode celup pakan). Lethal concentration (LC) pada 5 hari setelah perlakuan, $L C_{50}$ dan $L C_{75}$ pada aplikasi langsung sebesar 2,9\% dan 8,87\%, sedangkan pada aplikasi tidak langsung 6,99\% dan 21,03\%. Konsentrasi subletal tidak menyebabkan kematian S. litura tetapi mampu menghambat pertumbuhan yang diindikasikan dengan rendahnya bobot larva dan pupa S. litura. Asap cair limbah batang tembakau bersifat insektisida terhadap larva S. litura.

Kata kunci: aktivitas, asap cair, batang tembakau, Spodoptera litura

\section{INTRODUCTION}

Spodoptera litura is a significant pest on several agricultural commodities in Indonesia. Severe leaf damage due to this pest could decrease the crop production significantly. The control of this pest is mainly achieved by the use of chemical insecticide such as methyl parathion, chlorpyrifos, phosalone, endosulfan, deltamethrin and alphamethrin (Ramegowda, 2003). On the other hand, the use of the insecticide has lead to serious environmental pollution (water, air, and soil), pest resistance, pest resurgence, and toxicity to human (Dhaliwal et al., 2004; Horowitz \& Ishaaya, 2012). Therefore, the need of the future is to develop an eco-friendly approach to combat insect pests that should be able to regulate pest populations and safe to the environment. Recently, the use of botanical pesticide offered new possibilities of promising control techniques against insect pests.

The use of botanical pesticide as insecticide is an old practice and used all over the world. Botanical pesticide has been used widely both in small scale subsistence farming and commercial agriculture (Isman, 2008). A good botanical insecticide should fulfill some requirements before being developed, such as easier to produce in large quantities, not toxic to non-target organism, and has lethal effect to insect pest. Botanical pesticide has many advantages over chemical pesticide, such as minimal health hazards and environmental pollution, safe to non- 
target organism, no adverse effect on plant growth, and safe for humans (Pavela, 2014; Dimetry, 2014).

The development of botanical pesticide based on tobacco material has been progressing However, the use of tobacco stem extract is still limited, and so far there are no document on their potentials for a wider adoption for insect control. Therefore, further development of botanical pesticide based on tobacco stem waste product is needed.

Currently, one of the methods to utilize the potential of tobacco stem waste is by pyrolysis to produce liquid smoke which can be used as an insecticide againts $S$. litura. Liquid smoke is a product obtained from a process of chemical decomposition of organic materials by heating in a room with lack or no oxygen content to break the bonds of complex molecules into smaller molecular bonds (Czernik \& Bridgewater, 2004). The liquid smoke is containing several compounds that have function as an insecticide so it can be a natural substance to overcome pest problems (Tiilikkala et al., 2010; Tiilikkala et al. 2011).

Out of the long history of pyrolysis use, there can be found only a limited number of researches which focus on liquid smoke from tobacco stem as insecticide, and this is the subject of recent researches. Information on the toxicity of the liquid smoke from tobacco stem waste, as well as the activity of liquid smoke to the growth and feeding activity of S. litura, has not been available. Therefore, it is necessary to do research on this topic to provide information about the use of liquid smoke from tobacco stem waste as an insecticide that can be used by farmers to control larvae of S. litura in an eco-friendly way. The objective of this study is to determine the activity of liquid smoke of tobacco stem waste as an insecticide on $S$. litura larvae.

\section{MATERIALS AND METHODS}

The research was carried out at the Laboratory of Pest and Disease of Indonesian Sweetener and Fiber Crops Research Institute from August 2015 to January 2016.

\section{Extraction of Tobacco Stem Waste}

The tobacco stem was collected from tobacco fields in Karangploso Experimental Station and surrounding area of Malang, East Java. This experiment used Virginia Coker 176 variety. Two kilograms of tobacco stem were cut into small pieces approximately 2-4 $\mathrm{cm}$ in length . This material was put into a closed pyrolysis equipment. The smoke was destilated to obtain the liquid smoke and it was used for bioassay.

\section{Mass Rearing of S. litura Larvae}

Larvae of S. litura were collected from Karangploso Experimental Station, Malang, East Java. The larvae were allowed to feed on leaves of Chinese cabbage (Brassica rapa var. chinensis) in a plastic jar (1.5 $\mathrm{kg}$ ) that was covered with a gauze for ventilation under laboratory condition. They were kept until developed into pupae. The pupae were collected and placed inside of another plastic jar up to adult emergence. Male and female moths were allowed to mating and produce egg masses. The egg masses were kept for hatching. The newly hatching larvae were collected and reared on cabbage leaves to produce $2^{\text {nd }}$ instar. The second instar of F2 generation were used for bioassays.

\section{Bioassay of Liquid Smoke of Tobacco Stem Waste}

A preliminary test was carried out with concentration rates of $3.125 ; 6.25 ; 12.5 ; 25 ; 50 ; 100 \%$; and control. Each of concentration rates and control had four replications. Each replication used ten of $2^{\text {nd }}$ instar larvae.

A sprayer with low pressure compressor producing droplets of $2-3 \mathrm{~mm}$ in diameter was used to spray the test larvae with liquid smoke. The larvae were placed on a Chinese cabbage leaf of $4 \times 4 \mathrm{~cm}$ in size in a jar of $13 \mathrm{~cm}$ in diameter and $14 \mathrm{~cm}$ height of which a piece of filter paper was lined on under leaf. The larvae were then sprayed with liquid smoke according to the concentration rates. The plastic jar was then covered with gauze. The percentage of dead larvae was observed daily during five consecutive days after treatment.

The preliminary test was continued with the definitive test. The concentration rates of the liquid smoke adopted the rates used by Harwanto et al. (2012), i.e. $\mathrm{LC}_{10}, \mathrm{LC}_{25}, \mathrm{LC}_{50}, \mathrm{LC}_{60}, \mathrm{LC}_{75}, \mathrm{LC}_{95}$, and the control. Larvae and equipments used were similar to those used in the preliminary test. The seven levels of treatment (concentration rates) with four replication were arranged in Completely Randomized Design (CRD). Each of concentration rates used 15 larvae, hence, with each treatment had 60 larvae. Application of the liquid smoke was conducted by two methods, i.e spraying method (direct method) and feeding method (indirect method). The spraying method was done such as the same with the previous preliminary test. Meanwhile, protocol of the feeding method was as follows. A $4 \times 4 \mathrm{~cm}$ Chinese cabbage leaf was dipped into liquid smoke, and dried. The test larvae were allowed to feed on treated and untreated leaves in a jar which was covered with gauze.

Number of dead larvae were recorded daily during five consecutive days. Value of Lethal Concentration 
(LC) was determined by probit analysis using software of POLO Plus (Prijono,1999; Kranthi, 2005).

\section{The Effect of Liquid Smoke of Tobacco Stem Waste on Larval and Pupal Weight of S. litura}

In order to ascertain the effect of liquid smoke on larvae development, a test was carried out with sub lethal concentrations of $\mathrm{LC}_{25}(0.48 \%) \mathrm{LC}_{50}(2.07 \%)$, $\mathrm{LC}_{75}(8.89 \%)$ and the control was based on calculation from the definitive test (Syahputra, 2013; Syahputra $\&$ Prijono, 2011). Each of concentration rates including control used 25 second instar larvae. Treatment method and culture of larvae were same with those that conducted for the preliminary test. The cabagge leaf was replaced with the new one daily. The larvae were cultured until developed into pupae. Fresh body weight of the larvae were measured at 4, 7, and 10 days after treatment. Fresh body weight of the pupae were also measured. Analysis of variance and Duncan Multiple Range Test $\alpha=0.05$ were applied to determine significant effect of the treatment

\section{RESULTS AND DISCUSSION}

The activity of the liquid smoke of tobacco stems waste against the $S$. litura larvae was determined with the parameter of larval mortality and larval growth inhibition.

\section{Bioassay of Liquid Smoke of Tobacco Stem Waste}

The preliminary test in bioassay study resulted concentration rates from $\mathrm{LC}_{10}, \mathrm{LC}_{25}, \mathrm{LC}_{50}, \mathrm{LC}_{60}$, $\mathrm{LC}_{75}, \mathrm{LC}_{95}$ ca. $1.18 ; 2.911 ; 7.89 ; 11.49 ; 21.42$; and $89.98 \%$. The average percentage mortality from definitive test showed that liquid smoke of the tobacco stem waste was able to cause the death of S. litura larvae (Figure 1 and 2). The application of liquid smoke for 120 hours after treatment with spraying method and the feeding method was able to cause the mortality of $S$. litura as much as $95 \%$. On the second day of treatment, the mortality rate of $S$. litura was increasing. And on the fourth day, the mortality rate is above $80 \%$. These data showed that liquid smoke reacted slowly in destroying pest but was able to cause the death of the pest with the percentage of above $80 \%$. Figure 1 and 2 also show that there was a variation in the mortality rate of S. litura at each applied level of liquid smoke concentration. Increasing concentration was followed by increasing mortality of $S$. litura. This was made possible due to the fact that with increment concentration, the amount of poison exposed would be greater so that more larvae would be death.

$\mathrm{LC}_{50}$ value is used as one of the insecticidal activity criteria to the liquid smoke. The lower the $\mathrm{LC}_{50}$ value the more poisonous of insecticide. The results showed that spraying treatment method was more effective than feeding treatment method such as indicated by lower value of lethal concentration (LC) (Table 1). Within 5 days after treatment, $\mathrm{LC}_{50}$ was ca. $2.91 \%$ for spraying method which was lower than ca. $6.99 \%$ for the feeding method. It is implies that the liquid smoke when to be sprayed may kill directly to the target pest or indirectly by feeding leaves containing residues of the liquid smoke.

The activity of the liquid smoke of tobacco stem waste was agree with the results of previous researches. For example, the uses of liquid smoke of laban wood with a concentration of $5 \%$ caused the death of termite Coptotermes curvignatus up to $100 \%$ (Oramahi et al., 2014). The liquid of coconut shells were able to cause death of Nilaparvata lugens up to $100 \%$ (Wagiman et al., 2014). The liquid smoke of birch wood caused the death of Myzus persicae up to $95 \%$ (Tiilikkala et al., 2010). The liquid smoke of tomatoes and tobacco leaves was able to kill Leptinotarsa decemlineata up to $80 \%$ and $94 \%$ respectively (Booker et al., 2010; Caceres et al., 2015).

According to Kim et al. (2008), most of the properties of liquid smoke as a contact poison are caused by the acetic acid contained in the liquid smoke which could damage the cuticle permeability of an insect causing it to die. Other researches also show that the liquid smoke works better in contact than if it is fed or applied indirectly. Application of the liquid smoke of coconut shell on brown planthopper also has a lower concentration of LC in the direct method (spray method) when compared with the indirect or feeding method (Wagiman et al., 2014).

\section{The Effect of Liquid Smoke of Tobacco Stem Waste on Larval and Pupal Weight of S. litura}

In order to ascertain the sub-lethal effect of liquid smoke of tobacco stem waste on $S$. litura, an observation was conducted on the development of $S$. litura which had been applied with liquid smoke by using the parameter of larvae weight four, seven, and ten days after treatment, and measuring the pupal weight. The sub lethal concentration did not cause mortality of S. litura larvae, but inhibited the growth such as indicated by lower weight of treated larvae than the control ones (Table 2). The survival larvae had the ability to neutralize or detoxify the poison that enter the body so that the poison did not cause death. However, the consequence was that the detoxification process needs energy from the body, which should have been used for growth and development of the insect. This naturally resulted in an inhibition of the insect growth, vis-à-vis a healthy insect (Farrar, 1989). This was the reason why the application of the liquid 


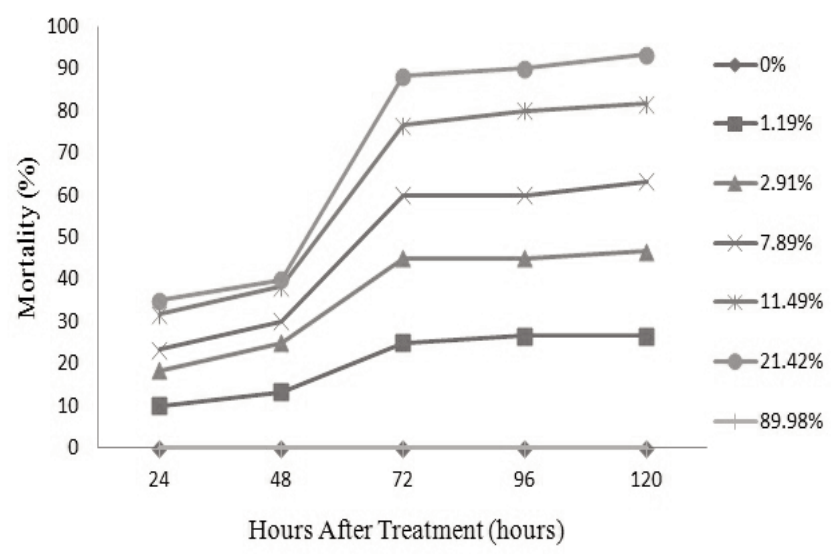

Figure 1. Effect of liquid smoke of tobacco stem waste applied with spray method on definitive test against Spodoptera litura mortality at 120 hours after treatment



Figure 2. Effect of liquid smoke of tobacco stem waste applied with feeding method on definitive test against Spodoptera litura mortality at 120 hours after treatment

Table 1. Lethal concentration (LC) of liquid smoke of tobacco stem waste against Spodoptera litura on 120 hours after treatment

\begin{tabular}{cccc}
\hline & \multicolumn{3}{c}{ Lethal concentration } \\
\cline { 2 - 4 } & $\mathrm{LC}_{25}(\mathrm{CI} 95 \%)(\%)$ & $\mathrm{LC}_{50}(\mathrm{CI} 95 \%)(\%)$ & $\mathrm{LC}_{75}(\mathrm{CI} 95 \%)(\%)$ \\
\hline Spraying method & 0.483 & 2.911 & 8.87 \\
& $(0.19-0.87)$ & $(1.24-2.99)$ & $(6.44-12.91)$ \\
Feeding method & 2.320 & 6.985 & 21.03 \\
& $(1.43-3.28)$ & $(5.21-9.23)$ & $(4.62-10.26)$ \\
\hline
\end{tabular}

Table 2. Effect of liquid smoke of tobacco stem waste on larval and pupal weight of Spodoptera litura

\begin{tabular}{lccccc}
\hline $\begin{array}{c}\text { Concentration rate } \\
\text { of liquid smoke (\%) } \\
\text { (equal to LC) }\end{array}$ & $\mathrm{n}^{\mathrm{a}}$ & $\begin{array}{c}\text { Larval weight } \\
\text { four days } \\
\text { after treatment } \\
\text { (gram) }\end{array}$ & $\begin{array}{c}\text { Larval weight } \\
\text { seven days } \\
\text { after treatment } \\
\text { (gram) }\end{array}$ & $\begin{array}{c}\text { Larval weight } \\
\text { ten days } \\
\text { after treatment } \\
\text { (gram) }^{\mathrm{b}}\end{array}$ & $\begin{array}{c}\text { Pupal weight } \\
\text { (gram) }\end{array}$ \\
\hline Control & 25 & $0.08 \pm 0.03 \mathrm{~b}$ & $0.40 \pm 0.02 \mathrm{c}$ & $0.57 \pm 0.09 \mathrm{~b}$ & $0.29 \pm 0.01 \mathrm{c}$ \\
$0.48\left(\mathrm{LC}_{25}\right)$ & 25 & $0.06 \pm 0.01 \mathrm{ab}$ & $0.23 \pm 0.10 \mathrm{~b}$ & $0.35 \pm 0.05 \mathrm{a}$ & $0.21 \pm 0.01 \mathrm{~b}$ \\
$2.07\left(\mathrm{LC}_{50}\right)$ & 25 & $0.04 \pm 0.02 \mathrm{a}$ & $0.15 \pm 0.02 \mathrm{ab}$ & $0.33 \pm 0.05 \mathrm{a}$ & $0.19 \pm 0.01 \mathrm{a}$ \\
$8.89\left(\mathrm{LC}_{75}\right)$ & 25 & $0.04 \pm 0.01 \mathrm{a}$ & $0.13 \pm 0.02 \mathrm{a}$ & $0.28 \pm 0.01 \mathrm{a}$ & $0.18 \pm 0.02 \mathrm{a}$ \\
\hline
\end{tabular}

$\mathrm{a}=$ Number of larvae used per concentration.

$\mathrm{b}=$ The average in colloum followed by the same letter is not significantly different by DMRT $(\alpha=5 \%)$. 
smoke of tobacco stem waste caused the lower weight of larvae and pupa compared with the control. Result of the study indicated that the liquid smoke of tobacco stem waste had an insecticidal against larvae of S. litura.

\section{CONCLUSION}

The application of liquid smoke of tobacco stem waste with spray method and the feeding method was able to cause the mortality of S. litura up to $95 \%$. The spraying treatment method was more effective than feeding treatment method such as indicated by lower value of lethal concentration. Within 5 days after treatment, $\mathrm{LC}_{50}$ was ca. $2.9 \%$ for spraying method which was lower than ca. $8.87 \%$ for the feeding method. The sub lethal concentration did not cause mortality of $S$. litura larvae, but inhibited the growth such as indicated by lower weight of larval and pupal in treated larvae than in control. Liquid smoke of tobacco stem waste has an insecticidal activity against $S$. litura larvae

\section{ACKNOWLEDGMENT}

We are greatful to Prof. Ir. Y. Andi Trisyono, M.Sc., Ph.D, Prof. Dr. Ir. FX. Wagiman, S.U., Alex H.R., and Janis Damaiyani for suggestion on this article. This work was funded by Indonesian Agency for Agricultural Research and Development, Ministry of Agriculture.

\section{LITERATURE CITED}

Booker, C.J., R. Bedmutha, T. Vogel, A. Gloor, R. Xu, L. Ferrante, K.K.C. Yeung, I.M. Scott, K.L. Conn, F. Berruti, \& C. Briens. 2010. Experimental Investigations into the Insecticidal, Fungicidal, and Bactericidal Properties of Pyrolysis Bio-Oil from Tobacco Leaves Using a Fluidized Bed Pilot Plant. Industrial \& Engineering Chemistry Research 49: 10074-10079.

Cáceres, L.A., B.D. McGarvey, C. Briens, F. Berruti, K.K.C. Yeung, \& I.M. Scott. 2015. Insecticidal Properties of Pyrolysis Bio-oil from Greenhouse Tomato Residue Biomass. Journal of Analytical and Applied Pyrolysis 112: 333-340.

Czernik, S. \& A. V. Bridgwater. 2004. Overview of Applications of Biomass Fast Pyrolysis Oil. Energy \& Fuels 18: 590-598.

Dhaliwal, G.S., O. Koul, \& R. Arora. 2004. Integrated Pest Management: Restrospect and Prospect, p. 1, In O. Koul, G.S. Dhaliwal, \& G.W. Cuperus (eds.), Integrated Pest Management Potentials, Constraints, and Challenges. $\mathrm{CAB}$ International, London. UK.
Dimetry, N.Z. 2014. Different Plant Families as Bioresource for Pesticides, p. 1-3. In Dwijendra Singh (eds.), Advances in Plant Biopesticides. Springer Publishing, India.

Farrar, R.R,, J.D. Barbour, \& G.G. Kennedy. 1989. Quantifying Food Consumption and Growth in Insects. Entomologycal Society of America 89: 593-598.

Harwanto, E. Martono, A. Trisyono, \& Wahyono. 2012. Pengaruh Ekstrak Limbah Daun Tembakau Madura terhadap Aktivitas Makan Larva Spodoptera exigua. Biosaintifika 4: 2012.

Horowitz, A. \& I. Ishaaya, 2012. Advanced Technologies for Managing Insect Pest: An Overview, p.1-12. In I. Ishaaya, S. Reddy, \& A.R. Horowitz (eds.), Advanced Technologies for Managing Insect Pest. Spingerlink Publishing, London.

Isman, M.B. 2008. Perspective Botanical Insecticides: for Richer, for Poorer. Pest Management Science 64: 8-11.

Kim, D.H., H.E. Seo, S.C. Lee, \& K.Y. Lee. 2008. Effects of Wood Vinegar Mixted with Insecticides on the Mortalities of Nilaparvata lugens and Laodelphax striatellus (Homoptera: Delphacidae). Animal Cells and Systems 12: 47-52.

Kranthi, K.R. 2005. Conventional Bioassays, p. 8-10. In C.D. Mayee (ed.), Insecticide Resistance-Monitoring, Mechanism, and Management Manual. Central Institute for Cotton Research, New Delhi.

Oramahi, H. Ashari, F. Diba, \& Nurhaida. 2014. New Bio Preservatives from Lignocelluloses Biomass Bio-oil for Anti Termites Coptotermes curvignathus Holmgren. Procedia Environmental Sciences 20: 778-784.

Pavela, R. 2014. Limitation of Plant Biopesticides, p. 347-359. In D. Singh (ed.), Advances in Plant Biopesticides. Springer Publishing, India.

Prijono. 1999. Prinsip-Prinsip Uji Hayati, p. 9-13. In B.W. Nugroho, Dadang, \& D. Prijono (eds.), Bahan Pelatihan Pengembangan dan Pemanfataan Insektisida Alami. Pusat Kajian Pengendalian Hama Terpadu, Institut Pertanian Bogor.

Ramegowda, G.K., K.B. Goud, R.K. Patil, K.A. Kulkarni, \& I.G. Hiremath. 2004. Variability in Sensitivity of Spodoptera litura (F.) Populations Collected from Northern Karnataka on Groundnut to Insecticides. Karnataka Journal of Agricultural Sciences 17: 821-824. 
Syahputra, E. \& D. Prijono. 2011. Perkembangan dan Hambatan Makan Larva Crocidolomia pavonana yang Diberi Sediaan Fraksi Diklormetan Kulit Batang Calophyllum soulattri. Agroteknos 1: 135-140.

Syahputra, E. 2013. Insecticidal Activities of Barringtonia sarcostachys Bark against Cabbage Head Caterpillar Crocidolomia pavonana (F). International Society for Southeast Asian Agricultural Sciences Journal 19: 8-17.

Tiilikkala, K., L. Fagernäs, \& J. Tiilikkala. 2010. History and Use of Wood Pyrolysis Liquids as Biocide and Plant Protection Product. The Open Agriculture Journal 4: 111-118.
Tiilikkala, K., I. Lindqvist, M. Hagner, H. Setälä, \& D. Perdikis. 2011. Use of Botanical Pesticides in Modern Plant Protection. Pesticides in the Modern World-Pesticides Use and management/Edited by Margarita Stoytcheva. http://cdn.intechweb.org/ pdfs/21988.pdflnpapers2://publication/uuid/CDA8 DB4B-569A-433B-A157-D16148EEB624, modified 16/2/14.

Wagiman, FX. A. Ardiansyah, \& Witjaksono. 2014. Activity of Coconut Shell Liquide Smoke as an Insecticide on Rice Brown Planthopper (Nilaparvata lugens). ARPN Journal of Agricultural and Biological Science 9: 293-296. 